\title{
Fertilizers for Daphnia sp. (Crustacea, Cladocera) production in experimental tanks
}

\author{
Patrícia de Souza Lima Cunha ${ }^{1}$, Eduardo Arruda Teixeira Lanna ${ }^{2}$, Rafael Kopschitz Xavier \\ Bastos $^{3}$, Moisés Quadros ${ }^{1}$, Fabrício Pereira Rezende ${ }^{1}$, Leandro Monteiro de Freitas ${ }^{4}$ \\ ${ }^{1}$ Doutorando em Zootecnia/UFV. \\ 2 Departamento de Zootecnia/UFV. Bolsista CNPq. \\ ${ }^{3}$ Departamento de Engenharia Civil/UFV. Bolsista CNPq. \\ ${ }^{4}$ Graduando em Engenharia Sanitária e Ambiental/UFV.
}

\begin{abstract}
The current study was aimed at investigating the use of different fertilizers - dicalcium phosphate, biosolid and quail feces - as a strategy for water fertilization in Daphnia sp production. It was used twenty-four 100-L tanks of asbestos cement distributed in a completely randomized split-plot design with six replicates, with plots in the three kinds of fertilizers (biosolid, dicalcium phosphate, and quail feces) and a control without fertilization (WF) and subplots at the times of assessment (days 8 and 13). It was assessed the biomass production of Daphnia sp. and the following water quality parameters: chlorophyll a, electrical conductivity, $\mathrm{pH}$, dissolved oxygen, temperature, ammonia and organic nitrogen, total phosphorus and total hardness. There was a significant correlation between the values of chlorophyll a and biomass weight of Daphnia sp, which indicates interactions between phytoplankton and zooplankton communities. The maximum weight of Daphnia sp. biomass is found in tanks fertilized with quail feces (35.98 g), followed by the biosolid (16.80 g), control without fertilization $(6.75 \mathrm{~g})$ and dicalcium phosphate $(5.24 \mathrm{~g})$.
\end{abstract}

Key Words: biosolids, dicalcium phosphate, plankton production, quail feces

\section{Fertilizantes para produção de Daphnia sp. (Crustacea, Cladocera) em tanques experimentais}

\begin{abstract}
RESUMO - Este trabalho foi conduzido com o objetivo de avaliar a utilização de fertilizantes - fosfato bicálcico, biossólido e fezes de codorna - na água de produção de Daphnia sp. Foram utilizados 24 tanques de cimento-amianto, cada um com volume útil de $100 \mathrm{~L}$, em um delineamento inteiramente ao acaso em parcelas subdivididas com seis repetições, tendo nas parcelas os tipos de fertilizantes e um controle, sem adubação, e nas subparcelas as épocas de avaliação (dias 8 e 13). Foram avaliados a produção da biomassa de Daphnia sp. e os seguintes parâmetros de qualidade da água: clorofila a, condutividade elétrica, $\mathrm{pH}$, oxigênio dissolvido, temperatura, nitrogênio amoniacal e orgânico, fósforo total e dureza total Observou-se correlação significativa entre os valores de clorofila a e o peso da biomassa de Daphnia sp., o que indica interação entre as comunidades fito e zooplanctônicas. O peso máximo da biomassa de Daphnia sp. em tanques adubados com fezes de codorna é maior $(35,98 \mathrm{~g})$ que em tanques adubados com biossólido $(16,80 \mathrm{~g})$, sem adubação $(6,75 \mathrm{~g})$ ou adubados com fosfato bicálcico $(5,24 \mathrm{~g})$.
\end{abstract}

Palavras-chave: biossólidos, fezes de codorna, fosfato bicálcico, produção de plâncton

\section{Introduction}

The addition of fertilizers in nursery ponds is a common practice in aquaculture. The nutrients from fertilizers are incorporated into plankton biomass (phyto and zooplankton) and, through a complex web of assimilation and recycling, they reach the cultivated aquatic organisms (Mischke \& Zimba, 2004).

Regular additions of nitrogen should occur in nurseries, as fertilizers or rations, to keep its concentration high enough for abundant growth of phytoplankton and, consequently, to obtain higher productivity (Boyd, 1997).

The raise of natural food may be stimulated by the use of inorganic or organic fertilizers, which increases the availability of nutrients in the aquatic environment. Organic fertilizers have some advantages like the low cost, and it contains several macro and micro nutrients, however, it has variable availability and composition and may contain contaminants. On the other hand, inorganic fertilizers have advantages as the constant composition and availability, 
besides the easy adjusting levels of each nutrient, but it has a relatively high cost (Martínez-Córdova et al., 2004).

Manure, especially from poultry and pigs, has been used effectively for plankton production in natural food organisms ponds and in fish nurseries (Motokubo et al., 1988; Faria et al., 2000; Faria et al., 2001; Feiden \& Hayashi, 2005). The use of human excreta and sewage in fish farming is also a very old widespread practice around the world (Edwards, 1992; Bastos et al., 2003).

Every process of sewage biological treatment generates solid by-products (sewage sludge), which after properly treated and suitable for production applications are named biosolids. Those products have been used in farming practices as fertilizers or soil-conditioners (Andreoli et al., 2001). However, in aquaculture practices, there are no records of biosolids being used as fertilizers.

The knowledge of the natural food has an influence in culture environments, and in their increase because fertilization strategies of the water can contribute to a proper feeding management by increasing productivity and sustainability of the aquaculture production, and reducing costs. The current study was aimed at investigating the use of different fertilizers (dicalcium phosphate, biosolid and quail feces) as a strategy for water fertilization in Daphnia sp production.

\section{Material and Methods}

The experiment was conducted at the Departamento de Zootecnia of Universidade Federal de Viçosa, from February to March 2008, during thirteen days.

It was used twenty-four 100-L tanqs of asbesto cement, distributed in a completely randomized split-plot design, with three kinds of fertilizers (dicalcium phosphate, biosolid, quail feces) and a control without fertilization, with six replicates each.

All tanks received clean water, $500 \mathrm{~mL}$ of green water (with wild plankton) and $0.26 \mathrm{~g}$ of Daphnia sp. biomass.
Six tanks did not receive fertilizer applications. Biosolid tanks received $50 \mathrm{~g}$ of biosolids; dicalcium phosphate tanks received $50 \mathrm{~g}$ of dicalcium phosphate and quail feces tanks received $50 \mathrm{~g}$ of quail feces.

The experimental tanks were dried and exposed to the sun for five days. After that, they were filled with water (clean water) from UFV water supply network. The water was dechlorinated by chlorine volatilization for three days.

The green water (water with wild plankton), which was used in tanks, was produced in a $500 \mathrm{~L}$ tank with Nile tilapia fingerlings (Oreochromis niloticus) fed a commercial diet.

The chemical fertilizer composition was analyzed in Laboratório de Análises de Solo de Viçosa Ltda. (Table 1). Total levels of minerals were determined through acid extract (nitric acid with perchloric acid). Nitrogen was determined by Kjeldahl method and carbon monoxide by Walkley-Black method. Phosphorus was determined by colorimetry using Vitamin $\mathrm{C}$ as reductant. Calcium, magnesium, copper, iron, manganese and zinc were determined by atomic absorption spectrophotometer, and sulfur and boron were determined by colorimetry.

The physical and chemical water parameters were measured before the fertilizers application: $\mathrm{pH}$ using a digital pH meter, dissolved oxygen (DO) using a digital oximeter; temperature and electrical conductivity (EC) using a digital conductivimeter (measured in the experiment site - six replicates). Chorophyll $a$, total hardness, total phosphorous, organic and ammoniacal nitrogen were measured in laboratory (three replicates).

Water samples were collected and analyzed on days 8 and 13 of the experimental period, with each repetition consisting of a pool of two experimental unit samples.

The biosolid used in this study was produced from the sludge generated in the treatment of domestic sewage Sistema de Tratamento de Esgoto Doméstico (Viçosa MG); including an anaerobic reactor (UASB) plus a submerged aerated biofilter. The mud, already stabilized in

Table 1 - Chemical fertilizers composition

\begin{tabular}{|c|c|c|c|c|c|c|c|}
\hline Fertilizer & Nitrogen & Phosphorus & $\begin{array}{c}\text { Potassium } \\
0 \%\end{array}$ & Calcium & Magnesium & Sulfur & Cobalt \\
\hline Biosolid & 0.92 & 0.38 & 0.11 & 11.94 & 0.22 & 0.98 & 3.74 \\
\hline Dicalcium phosphate & 0.17 & 11.14 & 0.08 & 17.73 & 0.48 & 0.35 & 0.78 \\
\hline Quail feces & 4.79 & 2.55 & 2.96 & 9.69 & 0.55 & 0.41 & 8.42 \\
\hline Fertilizer & Zinc & Iron & $\begin{array}{c}\text { Manganese } \\
\text { ppm }\end{array}$ & Copper & Boron & Carbon/Nitrogen & $\begin{array}{c}\mathrm{pH} \\
\mathrm{H}_{2} \mathrm{O}\end{array}$ \\
\hline Biosolid & 542 & 25707 & 493 & 189 & 14.1 & 4.06 & 7.5 \\
\hline Dicalcium phosphate & 221 & 7751 & 451 & 50 & 10.5 & 3.90 & 3.3 \\
\hline Quail feces & 459 & 2219 & 468 & 60 & 50 & 1.75 & 6.7 \\
\hline
\end{tabular}


the treatment system was discarded on a sludge drying bed, where it remained until reaching the humidity level recommended for cleaning by addition of lime $(50 \%)$. Therefore, this material was mineralized and cleaned.

The laying quail feces were collected on the floor below the animal cages. Feathers, remnants of broken eggs and other impurities were removed and then the feces were dried and ground.

One day after fertilization, $500 \mathrm{~mL}$ of green water were inoculated, and after two days, $0.26 \mathrm{~g}$ of zooplankton (Daphnia sp.) was added into each tank. The physical and chemical water parameters were measured of the green water and it was found the following values for each of them: $\mathrm{pH} 8.1$, OD $5.9 \mathrm{mg} / \mathrm{L}$, temperature $22.2^{\circ} \mathrm{C}$, EC $189.3 \mu \mathrm{S} / \mathrm{cm}$, chlorophyll a $180.0 \mu \mathrm{g} / \mathrm{L}$, total hardness $48.22 \mathrm{mg} / \mathrm{L}$, total phosphorus $5.3 \mathrm{mg} / \mathrm{L}$, organic nitrogen $5.3 \mathrm{mg} / \mathrm{L}$. The value for ammoniacal nitrogen was not detectable.

The physical and chemical water tanks parameters were measured weekly. The water temperature was measured daily, at 8:00 a.m. and 6:00 p.m. The analyses were conducted at the Laboratório de Controle de Qualidade da Água da Universidade Federal de Viçosa according to methods described in Standard Methods for the Examination of Water and Wastewater (APHA, 1998).

At the end of the experiment, the water in each tank was filtered to get the biomass production of zooplankton (Daphnia sp.) in control without fertilization, biosolid, dicalcium phosphate, and quail feces tanks. The algal biomass (phytoplankton) was indirectly measured by the chlorophyll a parameter.

The experiment was conducted according to a completely randomized split-plot design, with plots in control without fertilization, biosolid, dicalcium phosphate and quail feces and subplots at the times of assessment (days 8 and 13), in a completely randomized design with six replicates. Data was analyzed by analysis of variance. The averages were compared using the Student Newman Keuls test $(\mathrm{P}<0.05)$.

Table 2 - Average values of chlorophyll $a$

\begin{tabular}{lc}
\hline Fertilizer & Chlorophyll $a(\mu \mathrm{g} / \mathrm{L})$ \\
\hline Control without fertilization & $0.83 \mathrm{~B}$ \\
Biosolid & $4.83 \mathrm{~B}$ \\
Dicalcium phosphate & $3.16 \mathrm{~B}$ \\
Quail feces & $52.33 \mathrm{~A}$ \\
\hline
\end{tabular}

Averages followed by equal letters do not differ $(\mathrm{P}<0.05)$ by SNK test.

\section{Results and Discussion}

The water temperature on tanks ranged from 24.6 to $30.0^{\circ} \mathrm{C}$ during the experimental period, which probably did not affect the zooplankton production, because water temperature recommended for cladocera growing is $24.4 \pm 4^{\circ} \mathrm{C}$ (Sipaúba-Tavares \& Rocha 2001).

The estimation of the chlorophyll $a$ values is often used as an indicative of the phytoplankton biomass (Esteves, 1998) and the environment trophic state. The values of chlorophyll $a$ was significantly $(\mathrm{P}<0.05)$ higher in tanks fertilized with quail feces $(52.33 \mu \mathrm{g} / \mathrm{L})$, followed by biosolid $(4.83 \mu \mathrm{g} / \mathrm{L})$, dicalcium phosphate $(3.16 \mu \mathrm{g} / \mathrm{L})$ and control without fertilization $(0.83 \mu \mathrm{g} / \mathrm{L})$ (Table 2$)$.

The higher values of chlorophyll $a$ in tanks fertilized with quail feces could have a correlation to the nutrients levels, also higher, in this fertilizer (Table 1), like the nitrogen and the carbon from carbon monoxide, which serve as essential nutrients for the algae growth. Similar results were found by Feiden \& Hayashi (2005) and Faria et al. (2000), who observed high planktonic organisms densities in ponds fertilized with poultry manure.

Nitrogen and phosphorus levels found in tanks with different kinds of fertilizers could be related to the fertilizers composition (Table 1).

The ammonia nitrogen values were different among the different fertilizers applied and the days of evaluation during the experimental period (Table 3). There was a correlation between the $\mathrm{N}-\mathrm{NH}_{3}$ pattern change and chlorophyll $a$ levels in tanks with the different fertilizers. The nutrient intake occured only at the beginning of the experiment and the biomass of the organisms increased during the experimental period, therefore, the nutrient consumption increased and the water ammonia nitrogen reserve were gradually depleted.

There was a higher availability of $\mathrm{N}-\mathrm{NH}_{3}$ (day eight) in tanks fertilized with quail feces, which could be correlated to the higher chlorophyll $a$ and organic nitrogen levels, a parameter that includes the algal biomass nitrogen. It was also found a correlation between organic nitrogen and ammonia nitrogen variations, and the reason for that could be the cellular synthesis of planktonic organisms from the ammonia consumption (ammonium ion).

Phosphorus values decreased in all tanks, except for dicalcium phosphate fertilizer, in which the chlorophyll $a$ concentration increased, probably because of the nutrients absorption by phytoplankton. There were traces only of phosphorus in tanks without fertilizer, and in tanks with 
Table 3 - Average values of water quality variables on days 8 and 13

\begin{tabular}{|c|c|c|c|c|c|c|c|c|}
\hline Item & \multicolumn{2}{|c|}{$\mathrm{N}-\mathrm{NH}_{3}(\mathrm{mg} / \mathrm{L})$} & \multicolumn{2}{|c|}{$\mathrm{N}$-organic $(\mathrm{mg} / \mathrm{L})$} & \multicolumn{2}{|c|}{ Total phosphorus $(\mathrm{mg} / \mathrm{L})$} & \multicolumn{2}{|c|}{ Total hardness $(\mathrm{mg} / \mathrm{L})$} \\
\hline Control without fertilization & $0.00 \mathrm{aD}$ & $0.00 \mathrm{aA}$ & $0.47 \mathrm{bC}$ & $1.63 \mathrm{aB}$ & $0.03 \mathrm{aD}$ & $0.05 \mathrm{aC}$ & $51.82 \mathrm{aB}$ & $49.86 \mathrm{aC}$ \\
\hline Dicalcium phosphate & $21.13 \mathrm{aA}$ & $0.00 \mathrm{bA}$ & $1.54 \mathrm{aB}$ & $1.68 \mathrm{aB}$ & $23.53 \mathrm{bA}$ & $57.85 \mathrm{aA}$ & $65.75 \mathrm{aA}$ & $61.89 \mathrm{aB}$ \\
\hline Quail feces & $3.85 \mathrm{aB}$ & $0.05 \mathrm{bA}$ & $2.52 \mathrm{bA}$ & $4.39 \mathrm{aA}$ & $4.12 \mathrm{aB}$ & $3.16 \mathrm{aB}$ & $61.99 \mathrm{bA}$ & $81.02 \mathrm{aA}$ \\
\hline
\end{tabular}

Averages followed by the same letter in line and capital letter in column do not differ $(\mathrm{P}<0.05)$ by SNK test.

dicalcium phosphate there was an increase of its values from the 1 st to 13 th day, which could be explained by the composition of this fertilizer.

The nitrogen values were higher than phosphorus values on the fertilizers composition, but did not reach the nitrogen and phosphorus ideal ratio (8:1) for the optimal growth of aquatic plants (Tundisi, 2003). Therefore, the nitrogen may have limited algal growth.

The total hardness values found in the control without fertilization, biosolid, dicalcium phosphate, and quail feces, certainly reflected the levels of calcium and manganese of fertilizers (Table 1) and correspond to the range recommended for aquatic organisms cultivation. The highest values were found in tanks fertilized with quail feces, followed by biosolid, dicalcium phosphate and control without fertilization (Table 3 ).

Levels of total hardness water above $20 \mathrm{mg} / \mathrm{L}$ are considered ideal for aquatic organism cultivation, assuring adequate calcium and magnesium levels (Sipaúba-Tavares, 1994).

The $\mathrm{pH}$ value on day 8 was significantly $(\mathrm{P}<0.05)$ high in tanks fertilized with biosolids and quail feces, and lower on those fertilized with dicalcium phosphate. In tanks without fertilization, the water $\mathrm{pH}$ value was intermediate in relation to the others (Table 4).

Those changes in $\mathrm{pH}$ values may have occurred because of the high photosynthetic activity on first eight days in tanks that had high phytoplankton production (biosolid and quail feces), with an increase of oxygen production and $\mathrm{pH}$ values, as a result of the higher carbon

Table 4 - Average values of $\mathrm{pH}$ for their combinations of fertilizers and days of evaluation

\begin{tabular}{lrc}
\hline Fertilizer & Day 8 & Day 13 \\
\hline Control without fertilization & $9.25 \mathrm{Ba}$ & $7.59 \mathrm{Ab}$ \\
Biosolid & $10.07 \mathrm{Aa}$ & $7.79 \mathrm{Ab}$ \\
Dicalcium phosphate & $7.72 \mathrm{Ca}$ & $7.11 \mathrm{Bb}$ \\
Quail feces & $10.03 \mathrm{Aa}$ & $7.83 \mathrm{Ab}$ \\
\hline
\end{tabular}

Averages followed by the same capital letter in column and small letter on line do not differ $(\mathrm{P}<0.05)$ by SNK test. dioxide $\left(\mathrm{CO}_{2}\right)$ consumption (Sipaúba-Tavares, 1994; Esteves, 1998). This increase of phytoplankton production may be related to greater nitrogen availability in these tanks. On the other hand, $\mathrm{pH}$ reduction from the eighth to the 13th day, which was higher in tanks fertilized with biosolid and quail feces, may be related to the organic matter deposition at the bottom of the tank, a phenomenon observed by Feiden \& Hayashi (2005) and Hayashi et al. (1999).

The dissolved oxygen value was significantly $(\mathrm{P}<0.05)$ high on tanks fertilized with quail feces, but there was no statistic difference between values from control without fertilization, biosolid and dicalcium phosphate (Table 5).

The increased dissolved oxygen values in tanks fertilized with quail feces was, probably, caused by the intensification of algae photosynthesis activity. In hypertrophic and low buffering capacity systems, photosynthetic organisms can greatly change the $\mathrm{pH}$ and availability of oxygen and nutrients, such as nitrogen and phosphorous (Pinto-Coelho, 1985).

There was a significant difference $(\mathrm{P}<0.05)$ between the electrical conductivity values of the different kinds of fertilizers and the control (Table 5). It was significantly high in tanks fertilized with quail feces. Electrical conductivity values were intermediate in tanks fertilized with biosolid and dicalcium phosphate and lower in control without fertilization.

The higher nutrient levels in quail feces could explain the higher electrical conductivity values in tanks fertilized with them (Table 1), as shown by Faria et al. (2001). Therefore, fertilizers with higher nutrients levels had

Table 5 - Average values of dissolved oxygenand electrical conductivity of treatments

\begin{tabular}{lcc}
\hline Fertilizer & $\begin{array}{c}\text { Dissolved oxygen } \\
(\mathrm{mg} / \mathrm{L})\end{array}$ & $\begin{array}{c}\text { Electrical } \\
\text { conductivity }(\mu \mathrm{S} / \mathrm{cm})\end{array}$ \\
\hline $\begin{array}{l}\text { Control without } \\
\text { fertilization }\end{array}$ & $5.04 \mathrm{~b}$ & $74.65 \mathrm{c}$ \\
$\begin{array}{l}\text { Biosolid } \\
\begin{array}{l}\text { Dicalcium } \\
\text { phosphate }\end{array}\end{array}$ & $5.41 \mathrm{~b}$ & $154.29 \mathrm{~b}$ \\
Quail feces & $5.44 \mathrm{~b}$ & $161.98 \mathrm{~b}$ \\
\hline
\end{tabular}

In each column, averages followed by equal letters do not differ $(\mathrm{P}<0.05)$ by SNK test. 


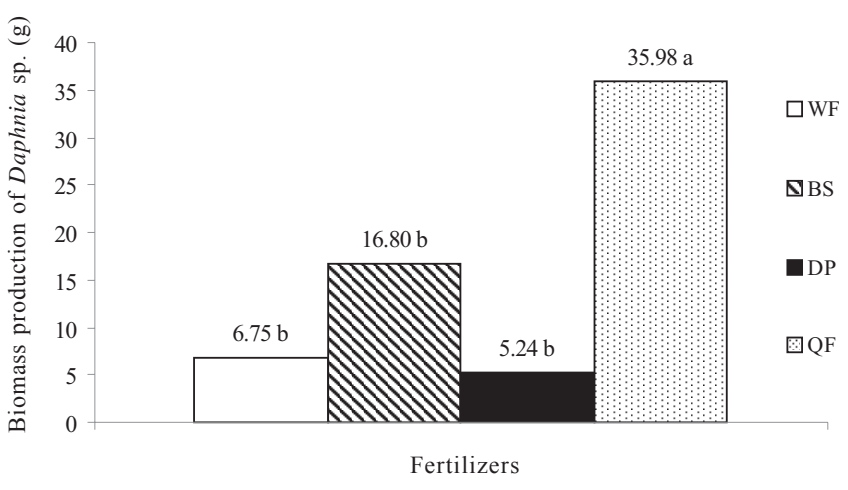

Figure 1 - Average weight (g) of Daphnia sp. biomass according to control without fertilization, biosolid, dicalcium phosphate and quail feces fertilizers. Averages followed by equal letters do not differ $(\mathrm{P}>0.05)$ by SNK test.

greater amount of salts dissolved in water and higher electrical conductivity values.

There was a significant correlation $(\mathrm{P}<0.05)$ between control without fertilization, biosolid, dicalcium phosphate and quail feces and the Daphnia sp. biomass production in tanks. The maximum weight of Daphnia sp. biomass was found in tanks fertilized with quail feces (35.98 g), followed by the biosolid (16.80 g), control without fertilization $(6.75 \mathrm{~g})$ and dicalcium phosphate $(5.24 \mathrm{~g})$, however, there was no significant difference between biosolid, dicalcium phosphate and control without fertilization (Figure 1). Similar results were found by Faria et al. (2000) and Soares et al. (1997), which observed higher plankton production in ponds fertilized with poultry manure.

The increased availability of nitrogen in ponds fertilized with quail feces provided further algae development, and because they were the main food source for Daphnia sp. kept in the experiment, tanks fertilized with quail feces had increased production of Daphnia sp. biomass.

There was a significant correlation between the chlorophyll $a$ values and the Daphnia sp. biomass weight, which indicates interactions between phytoplankton and zooplankton communities. These interactions can be explained by the fact that zooplankton are filter feeders microcrustaceans, which consume organic matter(phytoplankton, protozooplankton and the bacterioplankton responsible for decomposition of organic matter).

Although there was no significant difference on biomass production values, it was observed an increase of $149 \%$ in the Daphnia sp. biomass absolute value in tanks fertilized with biosolids in relation to the treatment without fertilization.

\section{Conclusions}

The fertilizer with higher nitrogen levels (quail feces and biosolids) is more efficient for plankton production. Supplementation only with phosphorus promotes smaller growth.

\section{References}

AMERICAN PUBLIC HEALTH ASSOCIATION, AMERICAN WATER WORKS ASSOCIATION, WATER ENVIRONMENT FEDERATION - APHA. Standard methods for the examination of water and wastewater. 20.ed. Washington, D.C.: APHA/AWWA/WEF, 1998.

ANDREOLI, C.V.; von SPERLING, M.; FERNANDES, F. Lodo de esgotos: tratamento e disposição final. Belo Horizonte: DESA/ UFMG, SANEPAR, 2001. 484p. (Princípios do Tratamento Biológico de Águas Residuárias, 6).

BASTOS, R.K.X.; PEREIRA, C.M.; PIVELLI, R.P. et al. Utilização de esgotos sanitários em piscicultura. In: BASTOS, R.K.X. (Coord.) Utilização de esgotos tratados em fertirrigação, hidroponia e piscicultura. Rio de Janeiro: ABES, RiMa, 2003. p.163-223. (Projeto PROSAB).

BOYD, C.E. Manejo do solo e da qualidade da água em viveiros para aqüicultura. Campinas: Departamento de Aqüicultura Mogiana Alimentos, 1997. 55p.

EDWARDS, P. Reuse of human wastes in aquaculture A technical review. UNDP-World Bank Water Research Program. Washington D.C.: The World Bank, 1992. 350p.

ESTEVES, F.A. Fundamentos de limnologia. 2.ed. Rio de Janeiro: Interciência/FINEP, 1998. 602p.

FARIA, A.C.E.A.; HAYASHI, C.; SOARES, C.M. et al. Avaliação dos grupos zooplanctônicos em tanques experimentais submetidos a adubação com diferentes substratos orgânicos. Acta Scientiarum v.22, n.3, p.375-381, 2000.

FARIA, A.C.E.A.; HAYASHI, C.; SOARES, C.M. et al. Dinâmica da comunidade fitoplanctônica e variáveis físicas e químicas em tanques experimentais submetidos a diferentes adubações orgânicas. Acta Scientiarum, v.23, n.2, p.291-297, 2001.

FEIDEN, A.; HAYASHI, C. Desenvolvimento de juvenil de Piracanjuba (Brycon orbignyannus), Vallencienes (1849) (Teleostei: characidae) em tanques experimentais fertilizados com adubação orgânica. Semina: Ciências Agrárias, v.26, n.4, p.591-600, 2005.

HAYASHI, C.; SOARES, C.M.; GALDIOLI, E.M. et al. Produção fito-zooplanctônica e alimentação natural de larvas de piavuçu (Leporinus macrocephalus, L) em tanques experimentais. In: ENCONTRO BRASILEIRO DE ICTIOLOGIA, 13., 1999, São Carlos, Resumos... São Carlos: SBI, 1999. p.531.

MARTÍNEZ CÓRDOVA, L.R.; CAMPAÑA TORRES, A.; MARTÍNEZ PORCHAS, M. Manejo de la productividad natural en el cultivo del camarón. In: SIMPOSIO INTERNACIONAL DE NUTRICIÓN ACUÍCOLA, 7., 2004, Hermosillo, Sonora, México. Memórias... Hermosillo: 2004. p.16-19.

MISCHKE, C.C.; ZIMBA P.V. Plankton community responses in earthen channel catfish nursery ponds under various fertilization regimes. Aquaculture, v.233, p.219-235, 2004.

MOTOKUBO, M.T.; ANTONIUTTI, D.M.; MAINARDES-PINTO, C.S.R. et al. Produção de zooplâncton em tanque de cultivo de curimbatá, Prochilodus scrofa, submetidos a diferentes fertilizantes orgânicos. Boletim do Instituto de Pesca, v.15, n.2, p.189-199, 1988.

PINTO-COELHO, R.M.P.; GIANI, A. Variações sazonais do fitoplâncton e fatores físico-químicos da água no reservatório do 
Paranoá, Brasília (DF). Ciência e Cultura (SBPC), v.37, n.12, p.2000-2006, 1985.

SIPAÚBA-TAVARES, L.H. Limnologia aplicada à aqüicultura. Jaboticabal: FUNEP, 1994.

SIPAÚBA-TAVARES, L.H.; ROCHA, O. Produção de plâncton (Fitoplâncton e Zooplâncton) para alimentação de organismos aquáticos. São Carlos: RIMA, 2001. 106p.
SOARES, C.M.; HAYASHI, C.; GONCCALVES, G.S. et al. Alimentação natural de larvas do cascudo preto Rhinelepis aspera Agassiz, 1829 (Osteichtchyes - Loricariidae) em tanques de cultivo. Boletim do Instituto de Pesca, v.24, n. especial, p.109-117, 1997.

TUNDISI, J.G. Água no século XXI: enfrentando a escassez. São Carlos: Rima, 2003. 248p. 